\title{
JOAQUÍN RUIZ-GIMÉNEZ: DEL DERECHO NATURAL A LOS DERECHOS NATURALES *
}

\author{
Elías Díaz \\ Universidad Autónoma de Madrid
}

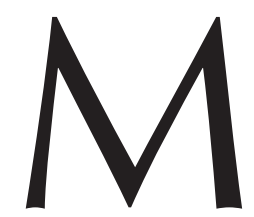

e parece significativo y muy positivo que la tan prestigiosa revista Doxa, haya pensado en acoger en sus páginas, por iniciativa expresa de su director M. ATIENZA, la evocación de la personalidad, el magisterio y la obra del profesor J. RuIZ-GIMÉNEZ con motivo de su fallecimiento avenido el 27 de agosto de 2009, recién cumplidos los noventa y seis años de edad: había nacido también en agosto, el día 2, de 1913.

Es significativa y relevante, creo, esta destacada recepción — no mera necrología gremial - por dos principales razones: una, reconozcámoslo, por y a pesar de ser la prevalente línea teórica de Doxa (analítica incluyente y plural, si se me permite tal calificación) muy diferente de la que aunque abierta y comprensiva hacía otras posiciones siempre ha caracterizado (iusnaturalismo que no prescinde de la religión) a la filosofía jurídica de aquél. Pertenecen, una y otra, a mundos más bien distantes en sus paradigmas conceptuales y metodológicos que, no obstante, en este caso comparten decisivos elementos comunes tanto de talante personal (diálogo y respeto hacia los demás) como de valores sociales e institucionales (derechos humanos y Estado de Derecho). La segunda razón sobre esa relevancia del recuerdo en Doxa a RUIZ-GimÉnEZ y a su entorno intelectual implica, a su vez, un necesario y generoso propósito de revisión, de recuperación, de no olvido: ello en especial para la más joven filosofía jurídico-política española actual, ante el no infrecuente desconocimiento y desinterés teórico y práctico respecto de lo que supusieron sus escritos y actividades públicas en aquellos tiempos del tardo franquismo, de la transición a la democracia e, incluso, de su influencia directa o indirecta para la misma Constitución. Convendrá señalar aquí que RUIZ-GIMÉNEZ fue, sí, un hombre de afectos (nadie o pocos negarían esto), pero fue también un hombre de conceptos (menos conocidos y/o reconocidos éstos).

Ambas mencionadas y comprensivas razones corresponden, pienso, a muy sanos criterios de justicia y honran tanto a nuestra revista como a nuestro maestro. A lo largo de estas páginas habrá ocasión para aportar pruebas y argumentos. Pero ya de entrada lo que yo me adelantaría a aducir como justificación fundamental, aunque no única, de todo ello, es el significado de su gran labor también personal como iusfilósofo pero,

\footnotetext{
* Fecha de recepción: 10 de diciembre de 2009. Fecha de aceptación: 10 de diciembre de 2009.

Este escrito, ahora in memoriam de J. RuIZ-GIMÉNEZ, procede de la relectura y reelaboración, con nuevas observaciones y precisiones, del capítulo a él dedicado en mi libro De la Institución a la Constitución. Política y cultura en la España del siglo XX, publicado (Madrid, Trotta, 2009) meses antes de su fallecimiento.
} 
sobre todo, su indudable mérito como eficaz aglutinante de las gentes e ideas que configuraron la revista y casa editora que fue de 1963 a 1976 Cuadernos para el Diálogo. Allí en esos trece años de puntual salida mensual y en los centenares de libros y folletos editados está buena parte de la cultura plural y del pensamiento político que enlazaría con la preexistente oposición a la dictadura y sin la cual no se entiende del todo la cultura política de la transición, ni la posterior construcción de la democracia en nuestro país. En las listas de quienes colaboraron en/con Cuadernos para el Diálogo están no pocos de los que serían después futuros protagonistas de ella y de la elaboración, como digo, de la propia Constitución.

Pero asimismo alegaría, ahora en un ámbito académico y de manera más concreta y específica, el apoyo personal e institucional que desde su cátedra proporcionaría RuizGIMÉNEZ para la renovación en plurales perspectivas de la filosofía jurídico-política en la Universidad española de aquellos años, como saben muy bien los hoy profesores y estudiosos que lo vivieron de cerca. Quienes entonces éramos sus jóvenes adjuntos pudimos así ocuparnos de indagar y publicar, por ejemplo, sobre un aquí inexistente Estado de Derecho (el autor de estas líneas, postulando un Estado democrático de Derecho) o, con las mismas ausencias, sobre los derechos humanos, G. PECES-BARBA quien andando el tiempo sería, en representación del PSOE, uno de los «padres» de la Constitución. Pienso que no poco de ello iba por entonces influyendo cada vez más en el propio Ruiz-GiménEZ. Como también lo harían las, entre otras, muy valiosas tesis doctorales realizadas en el marco de su cátedra por F. LAPORTA, E. LAMO DE ESPINOSA, V. ZAPATERO, E. FERnÁNDEZ y M. NúÑEZ ENCABO, sobre intelectuales de la «Institución Libre de Enseñanza», algunos de ellos (J. BESTEIRO y F. DE LOS Ríos), a su vez, destacados exponentes socialistas.

En ese contexto histórico y personal es en el que situaría yo aquí esta rememoración, sujeta a críticas y debates, sobre las aportaciones de aquel tanto las propiamente individuales como la parte de las colectivas propiciadas por aquel. No me corresponde entrar aquí en las de carácter más jurídico como profesional de la abogacía ni en sus defensas de destacados procesados políticos y sindicalistas durante todo este tiempo de la vida pública de nuestro país. Pero todo ello tampoco carecería de interés para la ciencia jurídica y la coherente crítica ética de sus presupuestos normativos validos y positivos.

\section{A PESAR DEL IUSNATURALISMO}

Conocí personalmente a J. RuIz-GIMÉNEZ en la primavera de 1956 cuando, escasas semanas después de ser destituido por Franco como ministro de Educación, se reincorporó a sus tareas docentes en la Universidad de Salamanca todavía dentro de ese curso 1955-56. Allí es donde, tras graduarme ese mismo año, comencé yo enseguida a colaborar con él, luego (en 1960) en la Universidad de Madrid, como ayudante en su cátedra de Filosofía del Derecho. Desde entonces (¡hace ya más de cincuenta años!), fue creciendo esa relación como maestro y amigo con cierta cercana e intensa asiduidad, mucho más en unas épocas que en otras, a lo largo de todo este incitante y complicado tiempo nuestro en el que, junto a otras cosas, se fueron acrecentando las vías de oposición para la transición de la dictadura a la democracia. 
Cuando con tal perspectiva me pongo a escribir (y ahora revisar) estas breves páginas, evocando y asumiendo desde este final esa dilatada experiencia, me complace poder comprobar y concluir con bastante certeza que, en su trayectoria vital, en su circunstancia histórica, respecto de la conformación de su carácter y su criterio, en la convicción y adaptabilidad de sus principios, RuIZ-GIMÉNEZ —esta es mi explícita conclusión - ha sido un hombre que fue siempre a más, que fue siempre a mejor, a mucho mejor. Hago aquí esta «medición» cualitativa desde valores —algunos, los más personales, presentes en él desde el principio - como los de solidaridad, dignidad humana, conciencia moral de la igualdad y la libertad, comprensión hacia los otros, movilización incansable y esperanzada en favor de todo ello que, en su evolución posterior, lo serían ya con plena coherencia para la consecución y fortalecimiento, en sus raíces individuales y colectivas, de una sociedad y de unas instituciones en vías realmente democráticas.

Esto, que considero objetivamente indudable, me parece que ha sido también muy relevante como incentivo vital toda su vida hasta el final con una feliz, fructífera y serena longevidad. Su criterio se ha construido en el diálogo, la generosidad y el profundo respeto a los demás. Hombre de profundas convicciones, incluso de utopías racionales, fue por entero consecuente con sus principios éticos pero, realista a la vez, sin olvidarse nunca ni despreciar para nada las efectivas consecuencias que pudieran producirse sobre los hombres y mujeres individuales, sobre la circunstancia social en la que aquellos operan. Hablando de esa su evolución, resultaría erróneo considerar que tal progresión vital de signo positivo sea algo que tiene siempre lugar en la existencia humana, en todos los individuos y, en concreto, respecto a su cualidad ética y/o intelectual, como un a modo de resultado natural de la mera madurez biológica, un atributo que se produce sin más en todos los hombres y mujeres cuando avanzan en experiencia y en edad. Por desgracia, no es ni mucho menos así: el estancamiento, el retroceso, el miedo, la renuncia, la abulia, la inhibición, pueden sobrevenir en una u otra escala en cualquier momento. Pero, por fortuna, tampoco es cierto que esos u otros similares males sean en modo alguno compañía ineludible de la ancianidad: además de en los mejores clásicos, tenemos ahora como buena prueba de ello un gran testimonio en el libro de N. BobBIo De senectute, otro gran maestro y amigo de muchos de nosotros, del cual hemos conmemorado en Turín y Madrid el centenario de su nacimiento, al igual que el de ARANGUREN entre nosotros a lo largo de este año de 2009.

Junto a todo ello, es ineludible comenzar afrontando aquí algo que todos sabemos: la profunda y perseverante presencia de la religión, de la fe cristiana, en la biografía, en las actividades y en los escritos de J. Ruiz-GimÉNEZ, su muy sincera y arraigada religiosidad. Pero yo discreparía enseguida de ciertas reducciones casi fideistas que en algún momento él haya podido propiciar sobre sí mismo. Así, cuando en una relevante e interesante entrevista de finales de los años sesenta ${ }^{1}$ concedía aquél acerca de sus religiosas dependencias: «debo reconocer que, efectivamente, de no ser por mi fe yo sería un burgués de la dolce vita, o de lo que fuere. Para mí —añade— sería mucho más cómodo, e incluso me lo podría autojustificar - y entonces sí que sería un opio de mí mismo-, mantenerme alejado de todo compromiso y de toda lucha social y política». No me lo creo, ni creo (con perdón) que él se lo creyera: con religión o sin ella (y sus

\footnotetext{
${ }^{1}$ S. PANIKER, Conversaciones en Madrid, Barcelona, Kairós, 1969.
} 
variantes entre una y otra), no veo de ningún modo a don Joaquín en esa supuesta vida disipada y frívola, mucho menos aún (porque en lo anterior me parece que exagera) desentendiéndose, displicente, ante las injusticias, las arbitrariedades y los abusos de poder, de los poderes, desoyendo insensible las peticiones de ayuda, de solidaridad, que las gentes, sobre todo las pobres gentes, pudieran dirigirle. No creo, como dice, que él eso se lo pudiera autojustificar.

Pero en esa misma indagadora entrevista se identifica mucho mejor poniéndolo en positivo y reenviando además de modo explícito a las dos dimensiones religiosa y secular que, sin plantearse posibles conflictos entre una y otra, le valen a él como fundamento de su sistema de valores. Decía allí RUIZ-GIMÉNEZ: «Mi primer motor es una exigencia de fidelidad a mi fe cristiana. Y mi fe cristiana me exige, por encima de todo, luchar contra la injusticia, la opresión y la alienación en que viven millones de hombres en el mundo. Ese es mi principal motor. En segundo lugar — señala enseguida el profesor de Filosofía del Derecho en esos años sesenta- mi enorme vocación jurídica a través de mi ocupación universitaria. Yo tengo que enseñar, todos los días del año, la teoría de la justicia, la existencia de derechos humanos, la idea de una comunidad de hombres libres y solidarios. ¿Cómo podría enseñar todo eso, si no tratara, al mismo tiempo, de vivirlo? Me sentiría terriblemente hipócrita frente a mis alumnos». «Y frente a sí mismo», le aduce con razón el entrevistador: «Y frente a mí mismo», confirma seguro J. RuIZ-GimÉNEZ. No era nuestro hombre de los que elaboran su ética teórica a espaldas de su ética práctica. Así, la conciencia, que en él es a su vez conciencia cristiana, se erige en su concepción como criterio básico, sustancial, para la construcción de la ética.

Y en el paso desde esta perspectiva más subjetiva y personal a otra con mayores exigencias de objetividad, incluso de universalidad, se constata con aún mayor claridad en la evolución intelectual, filosófica, de aquél esa misma superación del riesgo «fideista» que estaría siempre acechando en idearios donde la religión juega un papel tan principal. Veámoslo muy gráficamente: la primera edición, 1945, de su manual universitario, llevaba como titulo el de Introducción elemental a la filosofía jurídica cristiana; la segunda edición revisada, 1960, se delimitaba ya únicamente, y de ello se daban buenas explicaciones en sus páginas, como Introducción a la filosofía jurídica. No es que de 1945 a 1960 J. RuIZ-GIMÉNEZ hubiera dejado de ser cristiano; al contrario, quizás lo era ahora más auténticamente: y por ello, por no confundir ámbitos diferentes, prefería no hablar de «filosofía jurídica cristiana»; como años después, y por similares razones, se resistirá a adoptar, en otro orden de cosas, el rótulo de «democracia cristiana». Lo que hubo, no se olvide, es que en medio de aquellas dos fechas estuvieron las internas experiencias críticas de sus años italianos como embajador ante el Vaticano (19481951), como ministro de Educación (1951-1956) y como catedrático en Salamanca (1956-1960), etapas todas ellas —de la última, inicial mía, yo mismo puedo servir de modo directo y personal como testigo- sobre las que él siempre ha insistido fueron decisivas para las profundas transformaciones de su pensamiento y de sus actitudes.

Desde entonces, y hasta siempre, las categorías y dimensiones que van a ir paso a paso en él abriéndose camino y fortaleciéndose serán las de su identificación con la conciencia y razón de la modernidad, la tolerancia, el pluralismo, los derechos humanos, la filosofía política de ese carácter liberal y realmente democrática. En los inicios 
de los años sesenta, ya en la Universidad de Madrid (G. PECES-BARBA se incorporaría enseguida como profesor ayudante), la prosecución y ahondamiento de todo ello va a conducirle de modo consecuente a un talante religioso en plena identificación —siempre él eclesial, para bien y para menos bien (anotaría yo) - con el espíritu renovador del Papa Juan XXIII y el Concilio Vaticano II. Y a partir de ahí, pero en una dimensión más amplia y secular, más allá de esos límites, a la preparación y, después, aparición en 1963 de Cuadernos para el Diálogo, obra colectiva, pieza clave, junto a otras y junto a otros diferentes colaboradores, para esa movilización social y política, también religiosa y cultural, que impregnó la sociedad española y fue, a mi juicio, decisiva para la democracia en nuestro país.

Los escritos allí publicados por J. RuIZ-GIMÉNEZ entre 1963 y 1976, fecha en que aquélla concluiría como revista mensual de estudio y reflexión crítica (como semanario apareció todavía entre 1976 y 1978), están recogidos en los dos gruesos volúmenes editados en 1985 por el Centro de Estudios Constitucionales bajo el rótulo de El camino hacia la democracia. Este proyecto se había puesto en marcha por el autor de estas líneas en 1983, siendo entonces director de dicho Centro, como homenaje a nuestro maestro y amigo en la fecha de su setenta cumpleaños y de su jubilación universitaria. La realización efectiva de tal tarea, de reconocimiento y recopilación de dichos escritos, de ordenación de la cronología y situación explicativa de los principales de ellos, amen de varios relevantes estudios y una importante entrevista sobre el pensamiento de aquél, fue llevada felizmente a cabo por un valioso equipo del Instituto «Fe y Secularidad» —-destacaría desde mi perspectiva las aportaciones de J. A. GIMBERNAT y T. Rodríguez DE LECEA- y cuyo Director Académico, J. Gómez CAFFARENA, fue el autor de la Presentación general de la obra.

Estos escritos de RuIZ-GIMÉnEZ son fundamentales, como también los de otros numerosos y diferentes colaboradores de Cuadernos para el Diálogo (y de otras publicaciones, por supuesto), a modo de un ensayo general del pluralismo democrático, para un necesario entendimiento de fondo del contexto social, político, jurídico, cultural, en que iría gestándose críticamente la que luego sería la transición a la democracia en nuestro país. En este sentido he venido yo propugnando desde hace tiempo que habría sin duda que volver con detenimiento y conocimiento sobre todos estos materiales y documentación de Cuadernos para el Diálogo y del propio J. RuIZ-GimÉnEz. Para, entre otras cosas, evitar ilegítimas y excluyentes apropiaciones personalistas que, magnificando algunas forzadas y prudentes aportaciones de casi ultimísima hora (después me referiré a ello) están hoy pretendiendo suplantar y distorsionar lo entonces realmente acaecido, que fue mucho más colectivo, plural y de mayor coherente legitimación y legitimidad. La excelente tesis doctoral de J. MUÑOZ SORO — primer estudio de fondo sobre la historia y los contenidos principales de dicha revista- ha venido por fortuna, es decir por su esfuerzo y capacidad, a introducir no poca luz sobre estas y otros conexas cuestiones ${ }^{2}$.

2 Dicha tesis doctoral, revisada, Cuadernos para el Diálogo. Una historia cultural del segundo franquismo, ha sido publicada (con un breve Prólogo mío) por Marcial Pons Historia, Madrid, 2006. En la vida interna y externa de aquélla, suelo yo diferenciar dos grandes etapas: una primera, la más genuina y coherente, así la veía también RuIZ-GiMÉNEZ, de 1963 a 1969 (estado de excepción) y una segunda (1969-1976) con crisis y tensiones internas — como la derivada del golpe, en septiembre de 1973, contra el gobierno democrático de Salvador 
Desde otra dimensión, junto a la política, aunque complementaria de ella y que yo quiero destacar aquí de manera muy especial, esos escritos de J. Ruiz-GiméneZ son asimismo importantes — yo diría que «germinales»— para la reconstrucción de la fragmentaria y menos conocida y reconocida filosofía jurídica del catedrático de la Universidad de Madrid en esos decisivos años de 1963 a 1976. En estos dos volúmenes a través de las críticas a unas u otras manifestaciones concretas de la legalidad del Estado franquista y, en la medida de lo materialmente posible, también a su (carencia de) legitimidad, hay a mi juicio — es necesario llamar la atención sobre ello- formulaciones, argumentaciones y tomas de posición muy atendibles y valiosas sobre buena parte de los principales temas que preocupan y deben preocupar a la Filosofía del Derecho de nuestro tiempo. A diferencia de algún refinado distanciamiento iusfilosófico actual, hay allí una mucha mayor proximidad con los problemas reales de la colectividad y con la praxis política y el compromiso ético personal e intelectual. En su bibliografía y en su biografía académica constituyen, pues, estos escritos de Cuadernos una continuidad siempre en los fundamentos (cristianismo y iusnaturalismo) pero con muy profundos y decisivos cambios de contenido, de problemas y de respuestas concretas, (de carácter, yo diría, más ilustrado y democrático) respecto de aquel mencionado texto (manual) universitario de 1960.

No es, desde luego, el espacio de este escrito ni el lugar ni el momento oportuno para extenderme en un análisis pormenorizado de su estricta filosofía jurídica, ni siquiera para una consideración resumida de sus puntos de vista en cada uno de los grandes temas de ella. Quede esto para otros más específicos trabajos e investigaciones posteriores, ya más bien ajenas (por ejemplo, tesis doctorales), que auguro fructíferas, incluso en las necesarias posiciones críticas, que en todo caso serán ilustrativas de ese nuestro pasado. Aquí no haré sino destacar algunos puntos esenciales, básicos, de esa su filosofía: tal es, por ejemplo, el que se refiere a su genérica conformidad con la concepción iusnaturalista, o con aspectos de una u otra de sus manifestaciones. Suelo yo sintetizar el sentido de la progresiva evolución de RuIZ-GiménEZ en este tema como paso decisivo, no sin algún residuo, desde un iusnaturalismo de carácter más teológico (escolástica medieval) con primacía en la idea de orden — de todos modos tal ideario nunca por él estrechamente entendido- hacia un iusnaturalismo de fundamento más racional (Ilustración y modernidad) con primacía de los derechos humanos que derivan de la igual dignidad humana, del respeto a la libertad de la conciencia y de la solidaridad universal.

Así, cuando se le preguntaba «¿Sigue usted creyendo en el Derecho Natural?», recordemos cómo contestaba aquél en 1969 en términos que siguen siendo muy significativos de su actitud más consistente ${ }^{3}$ : «Creo que existen unos valores fundados en el sentido de la dignidad del hombre, en el sentido de la igualdad de todos los hombres. Lo que no creo - añade- es que el Derecho Natural sea una especie de código hecho de una vez para siempre. No fue esta la visión clásica — se ampara RuIzGIMÉNEZ-, ni es hoy posible sostenerla. Pero hay unas exigencias éticas humanas que piden ser cumplidas por el Derecho: si a ese Derecho se le quiere seguir llamando

Allende en Chile- que reencontrarían la básica y fundamental concordia, tras la muerte de Franco, con el proyecto común y plural de la transición y la Constitución democrática.

3 S. PANIKER, Conversaciones en Madrid, ya antes citadas. 
Natural, por mí —admite aquél— que se le llame así. Lo que importa son esas exigencias humanas, ese orden objetivo de valores. Si no — pregunta-, ¿qué sentido tendrían las declaraciones de los Derechos Humanos hoy vigentes?». Pero contesta bien el examinando-entrevistador PANIKER: «son libertades adquiridas» (más bien «conquistadas» precisaría yo, insistiendo en cualquier caso en el alto, altísimo, coste de tal «adquisición»). Y concluye el profesor RUIZ-GIMÉNEZ con algo que me parece de la mayor importancia, haciendo resaltar que esas libertades adquiridas «responden no a un acto formal de un legislador, sino a un reflejo de un nivel de la conciencia colectiva de la bumanidad. Yo creo - afirma- en una dinámica de la conciencia bumana. Si usted mira la declaración de los Derechos Humanos de 1948, ya le parecerá muy sobrepasada» (las cursivas, casi innecesarias, son mías para mejor reenlazar con lo que viene a continuación).

Proceso de afirmación, pues, del valor fundamental de la conciencia individual, de la autonomía moral, como cualidad insuprimible e irrenunciable de la dignidad humana, de todos los seres humanos por igual, en libertad y solidaridad. Y a su vez, carácter dinámico, abierto en el tiempo, de esa conciencia que, como conciencia colectiva de la humanidad cuya mejor y más auténtica expresión se hace a través de las vías democráticas. Por tanto, que sin «entificación de lo colectivo», sin transpersonalismos comunitarios, avanza reivindicando en la historia las exigencias éticas que, muchas veces sólo con grandes esfuerzos y luchas sociales, se van logrando reconocer e institucionalizar como derechos humanos, efectivamente protegidos y convertidos en realidad. Ante la importancia y solidez de tales propuestas, asumibles desde diferentes, plurales, concepciones, en cierto modo decae, pasa a un muy segundo plano (no digo que desaparezca) la cuestión más tradicionalmente filosófica, en ocasiones parece que es casi únicamente semántica, académica o gremial, de saber si a todo eso, como hacen los iusnaturalistas, se le puede o se le debe llamar Derecho natural.

Como hemos visto, Ruiz-GiméneZ no pondría excesivos reparos a ello. Pero es verdad que, con tal concesión, don Joaquín se aleja y se separa de los suyos, que —oponiéndonos a tal rótulo — tampoco son, somos, reductivos iuspositivistas. Pensamos con BoвBio que el Derecho natural ni es Derecho (sino ética) ni es natural (sino histórico) pero - ya con menos ayudas de BOBBIO- que los valores históricos algo más tienen que ver con la razón. En cualquier caso, aquél se nos hace así «amigo» de «enemigos» (en otros lugares he hablado y escrito, «en broma y en serio», acerca de esa peculiar —nada schmittiana- dialéctica ruizgimeniana), que son iusnaturalistas y dogmáticos apologetas de un Derecho Natural realmente contrario, o muy limitativo, de los derechos naturales (derechos humanos o fundamentales), como asimismo de la democracia y de la libertad. Con ellos Ruiz-GiménEZ no tiene nada que ver. No puede negarse, de todos modos, que todo eso, esa utilización, también puede darse con otros rótulos, en otras teorías, en otras familias incluso en las mejores, aunque me parece que con menor frecuencia y contundencia. Desde luego, el positivismo es, y ha sido, casi siempre, más liberal; y aún más que liberal, incluso en el mejor sentido de éste, podría serlo el de orientación socialdemocrática como suelen ser las críticas y autocríticas no iusnaturalistas del buen positivismo incluyente: no tanto del que excluye toda racionalidad a los juicios de valor. Hay base, pues, para proseguir el debate, también —como se ve- tomando a RUIZ-GIMÉNEZ como «pretexto». 
Pero por todo ello, por razones de coherencia, y a propósito de tal tradicional denominación de la que yo disiento, no quiero perder la ocasión (¡no hay muchas!) para criticar con cariño pero con severidad al «viejo maestro» por incurrir, como buen iusnaturalista, en el pecado que, con razón, se condena en la famosa falacia: el de llevar a la confusión, a la no suficiente diferenciación, entre el ser y el deber ser, entre los hechos y los valores. Otra cosa, pero no entro aquí en ello, es que algunos de los jueces de tal falacia, por evitar tal fusión y confusión, puedan a su vez ser criticados por producir y propugnar, o simular, la total separación, ruptura y escisión entre esos dos sectores - fáctico y valorativo- de la entera realidad. Pero es verdad que el iusfilósofo RuIZ-GIMÉNEZ también cometía tal pecado de iusnaturalismo incluso, contumaz, en la solemne ocasión de su jubilación cuando, rodeado de todos sus discípulos, nos dio -así la presentó él一 su Primera y última lección ${ }^{4}$. No era su primera, ni tampoco su última lección; había habido antes y hubo después muchísimas más; pero él quería así remarcar la radical relevancia de la cuestión allí planteada.

Relevancia, sin duda, emotiva y racional, en ese texto de su última clase universitaria oficial. Pero, como digo, también estaba en ella la tal falacia iusnaturalista de la que no hay más remedio que discrepar. Nos decía allí nuestro RuIz-GIMÉNEZ (las escasas pero significativas cursivas son, por supuesto, mías): «En los últimos días de mis clases ordinarias, os recordaba, mis jóvenes alumnos y mis amigos que el Derecho debe contribuir a encauzar los impulsos de agresividad que llevamos dentro, y a los que contribuyen, en gran medida, las circunstancias objetivas o las estructuras en las que vivimos. El Derecho — - seguía aquél y concuerdo plenamente con él— ba de abatir fronteras, eliminar factores de discriminación o desigualdad. Sólo así el Derecho será el auténtico ámbito de la libertad para todos los seres humanos. Sin ese respeto a la libertad de las personas, a la capacidad de despliegue de la personalidad humana - concluye RUIZ-GIMÉNEZ, metiéndose ya de lleno en las confusas redes del iusnaturalismo ontológico- no hay propiamente Derecho en una Comunidad, sino meras pautas mecánicas de existencia colectiva, fruto del Poder. El Derecho, hemos repetido muchas veces, necesita — sigue aquél— del Poder. Un Derecho sin Poder es algo inerte, dolorosamente ineficaz para encauzar la vida colectiva; pero un Poder sin sujeción al Derecho - y vuelvo, felizmente, a estar en total acuerdo con él y los dos con el Estado de Derecho- es la gran tragedia para cualquier colectividad humana». Lo que ocurre, don Joaquín - le recordaba yo en aquella ocasión — es que el Derecho injusto (Stalin, Hitler, Mussolini, Franco, Pinochet...) también es y ha sido, por desgracia, Derecho: no Derecho nulo sino Derecho válido, el que valía allí para resolver los conflictos, tomado a su vez como tal por jueces, abogados, ciudadanos (súbditos) y hasta los propios docentes universitarios.

Pero, más allá de estas no inocuas disidencias, a pesar del iusnaturalismo, recuperemos para finalizar este apartado lo que es sin duda más decisivo y radical, lo que nos es más común, desde una u otra posición, desde una u otra conceptualización: la defensa y potenciación de la autonomía moral, de la conciencia crítica, del diálogo, de los valores de libertad, igualdad y solidaridad que dan sentido y fuerza a los derechos humanos, a la democracia, al Estado de Derecho. Por todo esto ha luchado y siguió

${ }^{4}$ Publicada en la Revista de la Facultad de Derecho de la Universidad Complutense de Madrid, núm. 71, 1983. 
siempre luchando, en la teoría y en la práctica, sin perder nunca la esperanza, nuestro buen maestro y amigo. Concuerdo por ello con P. GONZÁLEZ BUENO (cercano colaborador suyo en los años como Defensor del Pueblo y después en Unicef) en que, a pesar de todo, este país no ha aprovechado de manera suficiente y adecuada, especialmente en estos últimos tiempos, a personas tan necesarias y relevantes como J. RUIZ-GiMéNEZ. Aquél se refiere también, y de nuevo concuerdo, a E. TiERnO GALVÁN, otro de mis «viejos maestros» desde aquella misma Salamanca de los años cincuenta por donde comenzaba yo ahora estas páginas (estos juicios de GONZÁLEZ BUENO proceden de la obra de J. L. GONZÁLEZ BALADO que se citará aquí más adelante, en la nota séptima).

Precisamente en razón de esa historia, de esas coincidencias y de sus valimientos, muchos, al menos muchos de sus amigos, yo también, nos sentimos andando el tiempo un poco culpables ante él. Le queríamos, le admirábamos, pero en 1977, en las primeras elecciones generales, cuando al fin llegó la democracia por la que RuIZGIMÉNEZ tanto había trabajado, no le votamos, no podíamos votar su lista electoral, opción demócrata-cristiana, a la que en contradicción interna se dejó entonces arrastrar. Algunos de aquellos amigos suyos pasaron al centro democrático (UCD), pero la mayoría - creo- estábamos ya, o desde tiempos atrás, en las opciones socialistas, ante las que él se retraía con simpatía y quizás, paradójicamente, por excesivo respeto y pudor histórico y personal. En algún momento anterior incluso habría escrito que «estuve a punto de dar un paso hacia el socialismo renovado». Se produjo —así se ha escrito- su «fracaso», su «naufragio» político. Pero nuestro hombre, que siempre en su vida supo ir a mejor, también entonces respondió muy bien: «No me ha venido mal el naufragio — sentenció-. Me ha permitido volver a actuar en algo que es para mí muy importante: la superación de las fronteras partidistas. Me parece interesante contribuir a estimular lo que une, más que lo que separa. A mí — confiesa — me cuesta mucho eso de la disciplina de voto dentro de un partido. No depender de ningún partido es algo que me va más». Pero — anoto yo- el indisciplinado RuIZ-GIMÉNEZ hubiera también podido contribuir a romper alguna de esas injustificadas y dogmáticas disciplinas.

Fuera de esa acción política de primera línea, parlamentaria, ejecutiva, partidaria, luego vinieron para él los tiempos de Defensor del Pueblo (1982-1987), con el triste e injusto final de su no renovación en 1988, evento sobre el cual otros buenos conocedores del «tema» como V. ZAPATERO han escrito con sinceridad y generosidad ${ }^{5}$. Y, enseguida, Presidente en España de Unicef desde 1988, acerca de cuya labor eficaz también sería necesaria una más detenida y profunda consideración: siempre se dolió aquél de que entre los poderosos del mundo (gobierno y sociedades) no hubiera mayor entrega, dedicación e interés hacia la terrible situación de la infancia en un mundo como el actual regido con mano férrea por el libremercado y la competitividad. El cristiano RUIZ-GIMÉNEZ siempre se sintió distante del nacional-catolicismo propio de la era franquista pero también, tiempo después, respecto del fundamentalismo teocrático (y del tecnocrático) que se expresa con fuerza en nuestros días a través de la coalición global entre neocons y teocons.

\footnotetext{
5 Así lo ha hecho, en efecto, V. ZAPATERO quien, como Ministro para las Relaciones con las Cortes, fue — «amargo trance» — el encargado de comunicarle el relevo dándole razones que — reconoce— «carecían de fundamento»: «Sin explicación convincente» se titulaba su artículo en la obra colectiva La fuerza del diálogo. Homenaje a Joaquin Ruiz-Giménez (Madrid, Alianza Editorial, 1997), pp. 259-262.
} 
En función de todo ello, de esa su actitud política, concordaría así aquél en la necesidad imprescindible de trabajar en y desde las instituciones, desde luego, pues es mucho lo que hay que hacer allí: recuperar y reconstruir las funciones fundamentales del Parlamento, luchar contra la corrupción, modernizar más la Administración, democratizar y abrir a los ciudadanos, y no sólo a los militantes, la participación y la toma de decisiones en los partidos políticos, liberar de si mismo al poder judicial, etc. Pero no es menor y menos radical la tarea que, cada vez con mayor conciencia de su necesidad y utilidad, se exige impulsar en y desde la propia sociedad: nuevos y menos nuevos movimientos sociales, organizaciones no gubernamentales, nacionales y transnacionales, acción del voluntariado, etc. Quizás más identificado finalmente con estas, como es común en tantos otros hombres del mundo de la cultura y del pensamiento, J. RuIZ-GimÉNEZ, estimulando más lo que une, seguía no obstante insistiendo a su vez en la ineludibilidad del trabajo político, jurídico, institucional. Es difícil pero imprescindible superar las crecientes incomunicaciones entre ambas, las mutuas impenetrabilidades entre instituciones jurídico-políticas y sociedad civil o movimientos sociales. Yo suelo hablar de homogeneidad crítica entre ambas. Todo es poco para avanzar en la transformación de fondo de las condiciones reales, sociales y personales, desde esos valores de libertad, igualdad, solidaridad, en definitiva de verdadera dignidad para todos los seres humanos. En esa, permítaseme, filosofía jurídica y política (también ética) es donde siempre era posible encontrarnos con nuestro buen maestro y amigo.

\section{DE MEMORIAS PERSONALES Y ACADÉMICAS}

Las anteriores críticas al iusnaturalismo de J. RUIZ-GIMÉNEZ, incluso a las implicaciones políticas de sus primeras etapas (en 1956, fecha de su cese como ministro, aquél estaba en los cuarenta y tres años de edad), venían asumidas en la laudatio doctoral mía a aquél, en 2000 en su investidura como Doctor Honoris Causa por la Universidad Autónoma de Madrid. En tal situación, que recupero aquí, resultan ineludibles e imprescindibles los recuerdos personales y sus contrastes, la memoria individual y colectiva, el testimonio de lo vivido por cada cual y de lo que no siempre queda constancia escrita. Pero, junto a ello, lo es aún más, desde luego, la historia que exige construirse sobre datos objetivos y del mayor rigor científico. Ambas categorías y dimensiones, memoria e historia, aspiran aquí a entenderse (en los dos sentidos de la palabra) y a coadyuvar a un mejor conocimiento de la realidad pasada y presente: en nuestro caso referida a la realidad (hechos y valores) de la política y la filosofía en la España contemporánea, ahora en concreto sobre pensamientos y actitudes de J. RUIZ-GIMÉNEZ.

Con ello, volviendo a hablar — como haré aquí brevemente- de sus trabajos y de sus días, evocando su biografía, me parece que se contribuye también a un mejor conocimiento histórico de algunos aspectos de esa segunda mitad de nuestro siglo XX. Pero, sin ruptura forzosa con lo anterior, tal historia fortalece asimismo la exigencia de una hoy - a mi juicio- muy necesaria recuperación de la mencionada memoria que se convierte entonces en más verdadera memoria histórica, personal y colectiva. «Estoy perdiendo la memoria», decimos y lamentamos continuamente a título individual cuando, de modo quizás irremediable, ya casi ni nos acordamos de cuando nos acordábamos. Y, sin embargo, por desgracia no siempre advertimos ni deploramos 
(más bien todo lo contrario) la correlativa pérdida de la memoria colectiva, es decir la que hace referencia a la comunidad. Pero es un hecho que aquí y ahora en democracia (tras la losa del sectario silencio dictatorial) en este país llamado España se siguen produciendo y propiciando, más en unos momentos que en otros, condiciones objetivas y subjetivas que han dado lugar a un poderoso, nefasto, temor ante las revelaciones de la que algunos no dudan en calificar de amnesia colectiva. Y casi peor que el olvido o la ignorancia es la distorsión, la manipulación, la prostitución de la memoria. Yo no creo que la transición a la democracia se hiciera desde el irresponsable olvido, pero tampoco creo que la memoria y la historia hayan sido respetadas como debieran. Hay mil ejemplos, el más luctuoso e inadmisible la existencia todavía de numerosos y anónimas fosas comunes donde fueron sepultadas, arrojadas, miles de personas asesinadas en aquellos tiempos de la desgraciada guerra incivil. Y esto pertenece también a la gran historia.

Entre nuestras pequeñas historias resituaría yo ahora, reduciendo lógicamente el diapasón para nuestro «tema», el hecho de que —-más allá de legítimas críticas- algunas de las desmemorias o distorsiones de ese reciente pasado han recaído injustamente también sobre la persona y la obra de J. RUIZ-GIMÉNEZ ${ }^{6}$. Vinculo a esto el testimonio de nuestro inolvidable amigo y compañero F. TOMÁs y VALIENTE. Precisamente en la que resultaría ser víspera fatídica de su vil asesinato por ETA, dentro de la Facultad de Derecho de la Universidad Autónoma de Madrid, aparecía en el diario El País, el martes 13 de febrero de 1996 — el crimen fue, recordemos, en la mañana del día 14_, un artículo suyo, redactado y enviado semanas antes, titulado así, precisamente y de modo escueto, Don Joaquín. Estuve muy cerca de la gestación e incitación de este escrito, en no pocas conversaciones y discusiones anteriores con él, pero ya no hubo después tiempo para volver sobre concordancias y discrepancias, que también las había: «tenemos que hablar» fueron de hecho las últimas, acuciantes, palabras que - al teléfono en nuestros muy cercanos despachos- yo le escuché, que él pronunció, aquella mañana segundos antes de que sobreviniera la tragedia. Hubiéramos hablado de lo que él decía allí pero también de otras cosas que en el fondo tenían no poco que ver con ello.

De todos modos, si evoco yo hoy aquí todo esto es también porque en dicho artículo aquél instaba, casi exigía, y con toda razón, a Ruiz-GiMÉNEZ para que escribiera sus Memorias. Me consta que, junto a insistentes peticiones anteriores y posteriores de otras gentes, entre las que me incluyo, aquella de F. TOMÁs y VALIENTE fue deter-

${ }^{6}$ Aduciré una muestra — a mi juicio- de ese olvido y desatención hacia la persona y la obra de J. RUIZ-GIMÉNEZ, así como hacia sus implicaciones en la cultura y política de este país a partir sobre todo de los años sesenta, aunado en este caso a una cómoda y sumisa preferencia por lo foráneo. En 2003, coincidiendo precisamente con sus noventa cumpleaños y los cuarenta de la aparición de Cuadernos para el Diálogo, inicié yo con decenas de amigos, colaboradores, discípulos y otros diversos profesionales, la presentación de su candidatura para los Premios Príncipe de Asturias de Ciencias Sociales o, en su defecto, de Humanidades y Comunicación. El primero le fue concedido a J. HABERMAS (nada que objetar salvo que previsiblemente al filósofo alemán le quedaría bastante más tiempo para legítimamente seguir optando a él) y el segundo a la escritora escocesa J. K. RowLING, creadora del famoso Harry Potter: con todos mis respetos y la devoción - ya lo sé- de tantísimos jóvenes lectores, incluida la de mi propio nieto, fue - creo- una decisión que en tal circunstancia concreta, aquí y ahora, veo muy difícil de justificar. He preferido no saber quiénes componían en tal ocasión la correspondiente Comisión de adjudicación: estoy seguro de que serían —como es habitual en dicha Fundación - personas competentes, buenas conocedoras de esos tiempos y para nada enemigas de nuestro candidato. Pero eso fue justamente lo que entonces más me disgustó y lo que ahora me sigue en amplia medida preocupando. 
minante para que aquél se pusiera decididamente a la delicada tarea de desempolvar y ordenar sus viejos y nuevos papeles. Estará ahí su complicada biografía: así, el más católico embajador ante el Vaticano, el arrepentido colaborador y ex-ministro de Franco (pero sin reacciones de rencor ni resentimiento personal), el inventor, fundador, inspirador y sustentador de Cuadernos para el Diálogo, posteriormente el decisivo armonizador de la «Plata-Junta» lograda en la transición por el conjunto de la oposición democrática, más tarde el Defensor del Pueblo y, finalmente, el valedor institucional de la infancia y de los refugiados políticos ${ }^{7}$.

Sus recuerdos, sus experiencias, sus reflexiones contribuirán, sin duda, muy eficazmente a superar esos olvidos e ignorancias pero también, como digo, a evitar no pocas de esas deformaciones y distorsiones a las que estoy haciendo aquí genérica referencia. Una de ellas, realmente muy importante, que silenciaba y falseaba gran parte de la historia de la transición a la democracia en nuestro país - grave de manera muy especial por la extraordinaria e incomprensible difusión concedida por entonces en importantes medios de comunicación — había colmado la indignación que estaba en el aludido trasfondo de este artículo de TOMÁS Y VALIENTE y era, además, expresamente criticada por él, historiador de profesión con absoluto fundamento y justificación. Tras evocar la trayectoria humana, política y profesional de RUIZ-GimÉNEZ hasta sus años como Defensor del Pueblo y en la Presidencia española de Unicef, don Joaquín — escribía aquél«acude a donde le llaman para tareas semejantes, aporta su cordialidad, sufre cuando se le ataca o se le omite, presencia cómo algún director general de Enseñanza Universitaria de los años cincuenta, que escaló después más altas cimas, asume ahora protagonismos póstumos y transitorios bajo apariencia de lejanas convicciones democráticas, y guarda, salvo en contadas ocasiones, un silencio discreto ante lo que ve y oye» ${ }^{8}$.

Ante frecuentes situaciones de ese o similar carácter, hay que seguir peleando, aunque las condiciones no sean siempre muy propicias, para no dejarnos meter de nuevo en otro, como aquel, «tiempo de silencio». Un silencio ahora diferente pero que en las actuales circunstancias se impone de manera mucho más sibilina y sofisticada en medio del gran estruendo, del inmenso ruido de la aparente comunicación global (con riesgos también de manipulación total) ejercida a través de las nuevas tecnologías y los nuevos, y no tan nuevos, centros de poder que con absoluta impunidad todo lo

\footnotetext{
7 Mientras tanto, mientras llegan sus Memorias, puede consultarse para esos y otros datos biográficos, junto a otras obras ya citadas, el libro, útil e interesante pero algo desigual, de J. L. GONZÁLEZ-BALADO, RuizGiménez, talante y figura. Trayectoria de un hombre discutido (Madrid, Ediciones Paulinas, 1989), donde se recoge también el testimonio «no necesariamente elogioso, sino posiblemente crítico» de más de cuarenta «personajes públicos», dice el autor, entre amigos, colaboradores o que tuvieron alguna relación, incluso muy discrepante, con él.

${ }^{8}$ Las referencias críticas de F. TOMÁs y VALIENTE en este artículo - y en nuestras mencionadas conversaciones previas - lo eran, obviamente, al libro por entonces aparecido (y de modo incoherente profusamente difundido) de P. y A. Fernández-Miranda, Lo que el Rey me ha pedido. Torcuato Fernández Miranda y la reforma política, Barcelona, Plaza y Janés, 1995: un ejemplo explícito de esta concreta distorsión, el resto es silencio, puede encontrarse en la p. 339, nota 2 del cap. IV de la obra. Tuve ocasión de comprobar, dentro de su habitual mesura y discreción, que a RUIZ-GIMÉNEZ también le habrían disgustado seriamente tanto esos olvidos «saduceos» como el increíble confusionismo mediático posterior. Como base de la personal posición que yo vengo manteniendo ante el trasfondo de estas cuestiones, me permitiría reenviar, entre otros, a mis libros $L a$ transición a la democracia. Claves ideológicas, 1976-1986 (Madrid, Eudema, 1987, especialmente epígrafe 26), y Ética contra política. Los intelectuales y el poder, Madrid, Centro de Estudios Constitucionales, 1990, especialmente cap. IV, 3, «Las ideologías de (sobre) la transición».
} 
dominan, lo trituran y lo distorsionan. Recuerdo como le decía yo por entonces a RuIZGIMÉNEZ, que, frente a tales poderes y sus apologetas, deberíamos volver a lanzar los nuevos mensuales Cuadernos para el Diálogo del siglo XXI. No eran ya posibles, pero por lo menos los alego yo aquí en su biografía, los publicados entre aquellos años de 1963 a 1976, cuando nadie o muy pocos, casi ni siquiera todavía HABERMAS, hablaban de diálogo como argumentación racional, como razón y voluntad de comunicación en cuanto «situación ideal de diálogo». Aquellos Cuadernos fueron - a mi juicioun hito importantísimo, imprescindible, para la reciente historia política e intelectual (también universitaria) de este país y su ejemplo también debiera serlo en los actuales tiempos para no resignarnos a este mediocre presente y para su necesaria transformación en un mundo futuro con algo más de esperanza, de solidaridad y de calidad humana. De J. Ruiz-GimÉNEZ, de Cuadernos para el Diálogo, puede decirse que sin él, sin ellos, todo habría sido mucho más difícil y mucho más pobre en todo este tiempo nuestro que intentaba salir de la dictadura y construir en libertad una sociedad más justa y un Estado democrático?

Y también hay en ellos, en los viejos Cuadernos, aportaciones muy validas y significativas para esa necesaria recuperación, con que se iniciaban estas páginas, respecto de aquellas cuestiones propias de la filosofía jurídica, ética y política. El profesor L. Hierro en una, por él así titulada, Nota demasiado breve sobre lo que la Filosofía del Derecho española debe al profesor Ruiz-Giménez —nota breve aunque muy enjundiosa, añadiría yo- ha rememorado algunas de aquellas conflictivas y agresivas vicisitudes de nuestra «disciplina» durante el franquismo con el férreo y neurótico caudillaje ejercido en ella por un despótico capo académico del tradicionalismo ultramontano (me refiero al catedrático don F. E. DE TEJADA Y SPíNOLA) acompañado siempre de sus atemorizados y/o aprovechados colegas y acólitos. Como resistencia, casi como mera subsistencia, ante tal situación iba a ir surgiendo en torno precisamente a RUIZ-GIMÉNEZ la «escuela» o «movimiento» de disidencia intelectual y de reconstrucción iusfilosófica que se configura con la colaboración — recuerda aquél— de sus dos adjuntos, E. DíAZ y G. PeCES-BARBA, en años que acota, quizás un tanto estrictamente, entre 1963 y $1974^{10}$. Tras los dos adjuntos y con buenas ayudas externas vendrían después, en esas comunes y plurales vías (cito sólo, y por ordenes temáticos doctorales, a los ya más seniors) F. LAPORTA, V. ZAPATERO, E. LAMO DE ESPINOSA (posteriormente reconvertido a la Sociología), M. NúÑez Encabo, E. Fernández, M. Atienza, L. Hierro, A. Ruiz Miguel, J. Ruiz Manero, L. Prieto, J. Ramón de PÁramo y otros hoy ya también catedráticos de diferentes Universidades. Como se ve, mucho de lo mejor de la Filosofía

\footnotetext{
9 Una amplia y valiosa consideración de sus aportaciones en los diversos ciclos y oficios de su biografía puede encontrarse en la obra colectiva, ya mencionada aquí, La fuerza del diálogo. Homenaje a Joaquín RuizGiménez, con la participación de más de sesenta colaboradores como muy sucinta muestra de sus amigos y compañeros; allí va también una entrevista biográfica con él, hecha por T. RODRÍGUEZ DE LECEA, y una útil cronología que puede ayudar a situar mejor algunos de los datos (hechos y fechas) personales y generales a los que se alude en estas páginas mías.

${ }_{10}$ Nota del profesor L. HierRo publicada, como digo, en la obra colectiva citada en la nota anterior. En esta misma obra pueden verse, sobre algunos de esos temas más relacionados con sus tareas universitarias, mis propias anotaciones, A pesar del iusnaturalismo (pp. 87-98), y, en un plano universitario de carácter más general, las de G. PECES-BARBA, Joaquín Ruiz-Giménez, educador de muchedumbres (pp. 99-105), de R. MESA, La Universidad de don Joaquín y sus universitarios (pp. 107-112) y de J. MuguerZA, El (in)cesante Ruiz-Giménez (pp. 287-290).
} 
del Derecho española actual que sin el profesor RuIZ-GiméNEZ en aquellos tiempos no hubiera podido empezar a respirar. Tampoco habría que olvidar aquí a gentes de mi generación que estuvieron personalmente cercanas como fue, de manera muy principal, L. GARCÍA SAN MigUEL.

Entre aquéllos se compartieron de manera plural, no uniforme, líneas de trabajo e investigación: así, la recuperación del reciente pensamiento heterodoxo español, el esfuerzo por la recepción de direcciones nuevas en la más destacada filosofía jurídica contemporánea, europea y americana, la crítica del Derecho natural teológico y tecnocrático, la lucha - teórica y práctica - por el Estado de Derecho y los derechos humanos, su traslación a la realidad política democrática de esos tiempos. Siempre don Joaquín favorecía y apoyaba esos y otros proyectos. Pero eso no quiere decir, por supuesto, que, en cuanto a su concepción general iusfilosófica, los docentes e investigadores antes citados sean o hayan sido «ruizgimenianos»; en modo alguno. Salvo en esos afectos, y en el reconocimiento de otras muchas cualidades suyas personales, desde el punto de vista teórico, de los conceptos, es claro que no lo somos ni siquiera PECESBARBA o yo mismo. No creo, por lo demás, que RuIZ-Giménez tenga o haya tenido el menor interés en rodearse de discípulos de esa igual condición. Esta ha sido una «escuela» (admitamos el término) muy poco o nada escolástica, sin escoliastas ni exégetas de una y única doctrina: más bien ha sido desde el principio germen de plurales direcciones y discrepantes orientaciones. Pero todos los citados y muchos más, eso sí, respetan, respetamos y queremos, a don Joaquín — reitero- por sus altas cualidades humanas, de generosidad, cordialidad, autenticidad y mil cosas más, pero también por su magisterio ético, político y jurídico, inspirado en los valores privados y públicos de rectitud, seriedad, espíritu de diálogo, de comprensión, de entendimiento otra vez en los dos sentidos de la palabra.

Y también le queremos y le reconocemos por — todo hay que decirlo- sus famosos (enternecedores) despistes. Le ocurría así al trastocar y mezclar con alguna frecuencia nombres y apellidos de gentes cercanas a él, o preguntar a un ya consolidado profesor titular por el estado más o menos avanzado de su tesis doctoral. Pero quizás el más característico y recordado de esos sus despistes tuvo lugar en aquellos años de la ahora Complutense cuando, en un Seminario restringido de Filosofía del Derecho, hizo sentar entre los asistentes al mismo, tomándole sin duda por alumno cualificado, a alguien desconocido para nosotros que se acercó queriendo hablar con él precisamente cuando íbamos a comenzar la sesión de trabajo. Hay que reconocer que dicha persona aguantó paciente, estoicamente, casi dos horas de matizadas disquisiciones y enconados debates sobre la kelseniana Grundnorm. De todos modos, recuerdo que fue prudente y que no llegó a intervenir ni a pronunciarse allí sobre tan arduas y complicadas cuestiones; y que fue sólo al final tímidamente, al requerirle don Joaquín su opinión, cuando nos expuso la verdadera razón de su presencia allí, que no era otra que la de ofrecernos e intentar vendernos —era representante comercial— un entonces último modelo de máquina de escribir. Descubrimos con horror que en su carpeta no llevaba notas sobre la Reine Rechtslebre, ni sobre el «centro de imputación», sino únicamente catálogos con sugerentes precios y buenas condiciones de venta de, me parece, la nueva Underwood: creo que le compramos dos. De ahí —en bromas y en veras—, de aquellos tiempos de lecturas, discusiones y oposiciones salió todo lo demás. 


\section{FILOSOFÍA JURÍDICO-POLÍTICA: DE LA FUNDAMENTACIÓN DE LOS FUNDAMENTOS A LA REALIZACIÓN DE LOS FUNDAMENTOS. EL CAMINO HACIA LA DEMOCRACIA}

El propio L. HIERRO en su ya mencionada Nota ha destacado asimismo con total acierto, entre otras muy serias cualificaciones de RUIZ-GIMÉNEZ, el carácter «radical» de sus convicciones dentro de la paulatina pero fuerte evolución experimentada por aquél a partir de 1956-1960: moderado en las formas y moderado en los «medios», pero ha sido — dice- «radical en las convicciones». También señala allí que aquél en su posterior tarea universitaria, docente e investigadora, «renunció — dice- a "interpretar" la Filosofía del Derecho y se dedicó a "transformarla" o, si se prefiere, a realizarla. El centro de esta actividad fue, por supuesto, Cuadernos para el Diálogo», concluye L. HIERRO ${ }^{11}$. Estoy sustancialmente de acuerdo, aunque creo que tal realización contribuyó también, aunque fuese de manera sólo segmentaria y no sistemática, a reinterpretarla.

La filosofía jurídica del profesor RuIZ-GimÉNEZ (permítaseme que, desde ahí y a propósito de ello, desarrolle yo un poco más estas reflexiones) siempre se ha preocupado y muy en serio por la profunda indagación y la consecuente afirmación de los fundamentos: esto me parece evidente. Pero no lo es menos que la suya no es ni ha sido nunca — conviene advertirlo - una filosofía fundamentalista ni en su sentido tradicional, ni en el que hoy retorna con demasiada frecuencia. Y no lo es, a mi juicio, por un doble tipo de razones: una, porque de sus fundamentos (tradición helénica y cristiana, ARISTÓTELES, TOMÁS DE AQUINO y Escuela española de los siglos XVI-XVII, muy básicamente) en todo momento ha intentado obtener coherentes consecuencias cambiables y abiertas, nunca cerradas y dogmáticas, ante nuevas lecturas y reinterpretaciones: y eso incluso, en sus épocas menos proclives hacia la filosofía y la política de la Ilustración y de la modernidad; dos, porque nunca se ha quedado ni en la glosa escolástica ni en el interiorismo de los fundamentos: al contrario, cada vez más y con mayor acierto —ya lo señala L. HIERRO- se ha ocupado de los medios de diferente cariz (económicos, políticos, jurídicos) que pueden hacer realidad esos fundamentos, esos fines.

J. RUIZ-GIMÉNEZ es ante todo un hombre de principios, de convicciones fuertes, «un cristiano cada vez más kantiano», reitero yo, que respeta muy seria y sinceramente la conciencia. Esto me parece fundamental; pero era también un hombre realista, que siempre asumía las propias responsabilidades y tenía muy en cuenta las repercusiones sociales, las consecuencias de los hechos y de los pensamientos, incluso - digamos con S. MiLL - las utilidades de ellos. Por su talante personal ¿podría haber sido en otras circunstancias un neokantiano en la estela, también diversa, de ORTEGA o, más aún, de sus casi maestros J. BESTEIRO y F. DE LOS RíOs? Intelectual y político, ha dejado bien probado que podría coincidir con M. WEBER en su intento por coordinar la Gesinnungsethik y la Verantwortungsethik: cuando éste - tratando de la ciencia y la política como vocación - habla de quien «siente realmente y con toda su alma esta responsabilidad por las consecuencias y actúa conforme a una ética de responsabilidad y que al

${ }^{11}$ Pp. 113-122 del trabajo citado en la nota anterior; y en concreto para los textos aquí aducidos, pp. 117 y 118. 
llegar a un cierto momento dice: «no puedo hacer otra cosa, aquí me detengo». (Ese «momento» — pienso yo— habría sido para RuIZ-GIMÉNEZ 1956-1963). «Esto — sigue el maestro alemán - sí es algo auténticamente humano»; y añade: «la ética de la responsabilidad y la ética de la convicción no son términos absolutamente opuestos, sino elementos complementarios que han de concurrir para formar al hombre auténtico, al hombre — concluye WEBER- que puede tener vocación política» ${ }^{12}$. No me parece nada desorbitado aplicar estas pautas y tensiones normativas al hombre, profesor y político, que en la España de aquellos años, finales de los cincuenta, se distanciaba de la dictadura (como aperturista todavía dubitativo) y comenzaba a orientarse hacia el mundo en que surgirían los libros y la revista de Cuadernos para el Diálogo (1936) en el marco de la casa editora por él fundada.

Hablando, pues, de fundamentos y de fundamentalismos, a favor de los primeros y en contra de los segundos, y aquí en relación con RuIZ-GIMÉNEZ, yo subrayaría que la investigación y reflexión sobre los medios (conscientes de lo que son), sobre los modos de acción — políticos, jurídicos, económicos, culturales—, no es, contrariamente a lo que muchos creen, de menor entidad científica y filosófica que la investigación y reflexión sobre los fines. Que éstos, separados y aislados de aquéllos, sobre todo cuando se trata de filosofía social, es decir de filosofía con decisivas repercusiones sociales, pueden llegar a convertirse en una metafísica que no sabe absolutamente nada de física. La filosofía es fundamentación pero no al margen de la realización: no es el cielo de los conceptos que nunca piensa en la realidad terrenal. Medios y fines siempre se interrelacionan. El fin no justifica los medios; son, con frecuencia, los medios los que justifican el fin; y, desde luego, que medios y fines tienen que justificarse juntos, más allá del eficientismo (empirismo) abstracto y del interiorismo (fundamentalismo) metafísico.

Todo esto se pone aquí en relación con el hecho de que la filosofía jurídico-política del profesor RuIZ-GIMÉNEZ —vuelvo sobre ese principal criterio interpretativo- es, fue en su primera fase (desde 1944, en que obtiene la cátedra y publica sus primeras obras, hasta 1956-1960, años en la Universidad de Salamanca) una filosofía preocupada, sobre todo y muy intensamente, por la afirmación y la profundización de los fundamentos: podríamos decir que por la fundamentación de los fundamentos, la cual se hace radicar, según sus lecturas, en el mencionado eje ARISTÓTELES, TOMÁs DE AQUino, Doctrina pontificia. Y habría, sin rupturas, una segunda fase (desde esas fechas en adelante) en donde el interés de su trabajo - teórico y práctico- se va a orientar mucho más, en efecto, hacia la realización de (esos) fundamentos, es decir hacia la investigación sobre los medios, hacia las vías para hacer reales aquéllos: o sea, sin expresar en principio ningún abandono en lo más esencial de los viejos fundamentos teológico-filosóficos, aunque sí con un mucho mayor espíritu de apertura hacia otras direcciones modernas del pensamiento y de flexibilidad en cuanto a las conclusiones concretas e históricas de los mismos.

No hay, pues, una ruptura, sí una ampliación y desarrollo — creo- en el radical fundamento de ambas fases - RUIZ-GIMÉNEZ no es un hombre de rupturas traumá-

${ }_{12}$ M. WeBER, El político y el científico, 1. ${ }^{a}$ ed. alemana, 1919; se cita aquí por la traducción española de F. Rubio Llorente, con extensa Introducción de R. ArOn, Madrid, Alianza Editorial, 1984, p. 176. 
ticas ni de conversiones súbitas-, pero sí hay cambios muy importantes en cuanto a consecuencias e implicaciones prácticas y de realización, aún también de alcance teórico y de no poco fondo. Entre otras, la de una plena, coherente y decidida asunción de la filosofía política democrática, su evolución hacia una filosofía jurídica reconstruida y reinterpretada con mucho mayor espacio para las libertades y los derechos humanos, un iusnaturalismo que invoca bastante menos el Derecho natural y mucho más los derechos naturales (en esto sería aquel mucho más cristiano que católico), así como una filosofía ética con más positiva base en la autonomía ilustrada de la conciencia individual y del diálogo como vías para el conocimiento ético y la objetividad de los valores. Ruiz-GiménEZ, hay que señalarlo a todos los efectos, se tomaba muy en serio los derechos humanos.

Sus obras del primer período La concepción institucional del Derecho (tesis doctoral) y, después, Derecho y vida bumana (Algunas reflexiones a la luz de Santo Tomás), ambas de 1944, así como la ya mencionada Introducción elemental a la Filosofía jurídica cristiana, de 1945, responden — junto a otros trabajos menores de la época- a esa que estoy llamando aquí filosofía, casi teología, de fundamentos, de fundamentación de los fundamentos ${ }^{13}$. Como señala el profesor E. FERNÁNDEZ, en su laudatio de 1997 para el doctorado Honoris Causa de aquél por la Universidad Carlos III, esas primeras obras «son, efectivamente, deudoras de unos planteamientos filosóficos muy tradicionales dentro de la más ortodoxa observancia del tomismo» y «sin embargo - subraya aquél - creo que se trata de libros rigurosos y bien trabajados y escritos, importantes para quien desee conocer la cultura y la filosofía jurídica de la época...» ${ }^{14}$. RUIZ-GimÉNEZ tenía entonces, cuando publica esas sus primeras obras, poco más de treinta años; en 1956, comienzo del final de esta etapa, cuando llega a Salamanca cesado por aperturista como Ministro de Educación —ya lo he recordado antes— todavía no había llegado a los cuarenta y tres, aunque nosotros los estudiantes le veíamos, tan serio e importante, como un señor mayor: de todos modos, sin comparación posible en esto con E. TIERNO GALVÁN que también estaba allí y que, cinco años más joven, era ya desde tiempos inmemoriales el V. P., el «viejo profesor» ${ }^{15}$.

13 Las dos primeras de esas obras se publicaron por el Instituto de Estudios Políticos, de Madrid; la tercera en Epesa, Ediciones y Publicaciones Españolas, S. A.

14 E. FERNÁNDEZ, «Laudatio» del profesor J. RuIZ-GIMÉNEZ, leída en el Acto de investidura de éste como Doctor «Honoris Causa» por la Universidad Carlos III, de Madrid, el 30 de septiembre de 1997, publicada después en la obra colectiva Horizontes de la Filosofía del Derecho. Homenaje a Luis García San Miguel, Ed. Virgilio Zapatero (2 vols.), Universidad de Alcalá, 2002. Sobre tal época y en esa misma obra colectiva, es imprescindible y con muy detallados datos el escrito de J. DELGADO PINTO, Breves notas sobre la evolución de la Filosofía del Derecho española entre 1960 y 1984. Asimismo, entre otros autores y revistas, puede verse el libro de B. RIVAYA, Filosofía del Derecho y primer franquismo (1937-1945), Madrid, Centro de Estudios Constitucionales, 1998, con utilísima documentación y, en ocasiones, discutible orientación. Y precisamente para los tiempos posteriores, el bastante más coherente de R. GARCíA MANRIQUE, La filosofía de los derechos bumanos durante el franquismo, Madrid, Centro de Estudios Constitucionales, 1996, epígrafes III, 3, 2 y V, 4, sobre RUIZ-GiMÉNEZ. Posteriormente, de esos dos mismos jóvenes autores, «Cronología comparada de la filosofía del Derecho española durante el franquismo (1939-1975)», Anuario de Filosofía del Derecho, t. XV, 1998, pp. 305 334. Otra información bibliográfica puede localizarse en mi libro Los viejos maestros. La reconstrucción de la razón, Madrid, Alianza Editorial, 2004, especialmente en su cap. V para el contexto de ese tiempo en la filosofía jurídica del profesor F. GONZÁLEZ VICÉN.

15 Para las relaciones entre ambos en aquellos momentos — con la irrupción de la generación del 56pueden verse, en la obra colectiva citada en la nota novena, las figuraciones conspiratorias, medio en broma medio en serio, de R. MORODO, tituladas De memorias salmantinas: Ruiz-Giménez, Tierno y el «feroz espía» 
Pero lo que estaba yo diciendo, insinuando más bien, es que si aquellos escritos, nada menos que del 44 y del 45 , se aliviaran de la presencia excesiva de citas eclesiales y pontificias, y, sobre todo, si se suprimen los aleatorios o circunstanciales alegatos «joseantonianos» y del nuevo Estado (como él mismo haría, sobre todo respecto a esto último) en su Introducción a la Filosofía jurídica, de 1960, veríamos mutatis mutandis, es decir aquí dentro siempre del sistema aristotélico-tomista, que —como escribía el otro clásico sobre HEGEL — «se descubre bajo la corteza mística la semilla racional» ${ }^{16}$. Nunca RUIZ-GimÉNEZ asume allí tal sistema de manera dogmática y cerrada, más bien al contrario con potencialidades humanistas que se harían después realidad. El profesor SANTOS JULIÁ ha aprovechado precisamente esas breves «insinuaciones» mías para, con estricto criterio cronológico, hacer una crítica a algunas de las implicaciones de los hipotéticos alivios de citas «joseantonianas» y pontificias en aquel RUIZ-GIMÉNEZ. Tal vez yo, a su vez, me excedí al meter ahí por medio el parangón Hegel-MarX. Pero tales insinuaciones no pretendían ser en modo alguno una, en sentido fuerte, «regla hermenéutica» sino sólo una forma leve de indicar que — a mi juicio- lo básico del talante de aquél desde siempre pero cada vez más a lo largo de los años cincuenta iba en ese sentido. Con los integrados pero no con los integristas, con los comprensivos nunca con los excluyentes, por decirlo en los términos del tan estimable D. RiDRUEJO. Eso y la evolución posterior, sobre todo después de 1956 (que yo viví muy de cerca) y con claridad ya desde el inicio de los sesenta es lo que más me interesaba resaltar a mí. Todo ello con independencia - relativa- de los enfrentamientos («en el interior del bloque dominante») entre falangistas católicos o no, y propagandistas de la «santa casa» versus tecnócratas del «Opus Dei», todos ellos con aliados en el núcleo duro del régimen ${ }^{17}$.

En cualquier caso, como digo, será ya después de 1956-1960 (este año gana por concurso-oposición la cátedra de la Universidad Complutense de Madrid), una vez recibida y asumida con pleno entusiasmo por él la benéfica influencia del Papa Juan XXIII y del Concilio Vaticano II, será ya claramente a partir de 1963, con la creación de Cuadernos para el Diálogo, cuando se inicia el compromiso en que se exterioriza for-

Elías Díaz (pp. 129-132): Cfr. después también otros diversos pasajes de la obra de R. Morodo, Atando cabos. Memorias de un conspirador moderado (I), Madrid, Taurus, 2001: hablando de su (nuestro) maestro, éste suele señalar con acierto que Tierno no era «viejo» sino más bien «antiguo» en sus formas y modales sociales.

16 K. MarX, a propósito de la filosofía de Hegel, en El Capital. Crítica de la Economía Política, postfacio a la segunda edición, 1873, pp. XXIII-XXIV en la versión en español de W. RocES, por la que aquí se cita, México-Buenos Aires, Fondo de Cultura Económica, 3. ${ }^{a}$ ed., 1964.

17 Este párrafo comentario sobre/con SANTOS JULIÁ era obviamente de nueva redacción para estos mis escritos de 2009. Mi laudatio a RUIZ-GIMÉNEZ era de 2000 y la documentada y polémica obra de SANTOS Julié, Historias de las dos Españas, de 2004 (Taurus): cfr. aquí, en concreto, p. 530, nota 75, y todos los capítulos 7 a 10 sobre ese periodo. Entre los numerosos artículos sobre dicha obra, destacaría yo el de A. GARCÍA SANTESMASES, «¿Eran de barro nuestros maestros? Sobre las raíces morales e intelectuales de la oposición política al franquismo», en la revista Isegoria, núm. 31, 2004. De necesaria lectura es la valiosa obra de J. GRACIA, La resistencia silenciosa. Fascismo y cultura en España, Barcelona, 2004: cfr. aquí, por ejemplo y como símbolo, pp. 260-261. Tengo escrito en otro lugar, por ello lo reproduzco aquí, que por talante o actitud de mayor comprensión y generosidad (ese es también un significado de «liberal»), así como de mayor compleja objetividad, me encuentro más cerca de GRACIA que de Juliá. Con este ha habido — dicho sea ya en pasado - algún que otro no buscado desencuentro: prefiero olvidar y pasar página (pero él lo dejó publicado y por eso aquí mi referencia) sobre algunas apasionadas y apresuradas críticas suyas contra un texto supuestamente mío pero que yo no había escrito, ni siquiera leído, ni conocido: por eso las califico de apresuradas y hasta de imprudentes; están en la revista Historia del presente, núm. 5, 2005, pp. 33-35; como en tantas otras ocasiones de la vida, si hubiésemos hablado previamente estoy seguro que se hubiera evitado el malentendido. 
malmente esa segunda fase de su pensamiento aquí denominado como de realización de los fundamentos. Realización, insisto en ello, también de carácter práctico-político (por todos reconocido) pero asimismo de alcance teórico-filosófico, indudable a mi juicio pero que exigirá todavía ulteriores relecturas para mayores precisiones y concreciones.

Rastreando precedentes, he señalado con propósitos polémicos que el escrito en que, otra vez, se manifiestan ciertos atisbos iniciales de ese tránsito, y la explícita exigencia — dice- del «diálogo» con los jóvenes, aunque todavía haya allí un fuerte anclaje ideológico en lo anterior, va a ser el texto base de su famosa conferencia de 1957 sobre La política, deber y derecho del hombre. Estábamos, no se olvide, en plena ebullición universitaria y cultural del post-56. Para el criterio de interpretación aperturista que estoy resaltando aquí (otros prefieren optar por criterios de implacable culpabilización) resulta enormemente significativo ver cómo abría RUIZ-GIMÉNEZ su muy meditada y calculada intervención. Decía así: «Innecesario parece advertir que no vamos a revisar ni a justificar aquí los supuestos antropológicos y metafísicos de la concepción del mundo - clásica y cristiana - sobre la que se apoya nuestra configuración ética y jurídica de la política, como deber y como derecho del hombre. Arrancamos — señala - de esos fundamentos por considerarlos vivos y verdaderos, más lozanos cada día; y nos apoyamos en ellos porque —advertía RuIZ-GimÉNEZ en el apenas elusivo criptolenguaje de la época- si hay actitud polémica en nuestras reflexiones es precisamente contra los que intentan manejar arbitrariamente esas mismas premisas para imponer a los sencillos ciudadanos, a los hombres de la calle, unas conclusiones gravemente ilegítimas» ${ }^{18}$.

Aunque no pueda extenderme yo ahora en los vericuetos de la política española de la época, para los relativamente informados quedaba claro — estuve presente en aquella memorable conferencia- a quiénes aludía persona tan mesurada como RuIZGIMÉNEZ en ese fuerte alegato «contra los que intentan manejar arbitrariamente esas mismas premisas» y a qué «conclusiones gravemente ilegítimas» se refería. Lo eran — dice- a quienes querían «revestir las transitorias razones de Estado con ropaje de permanentes razones de Dios. Las razones de Dios — insistía - son demasiado serias y grandes como para andar manipulándolas con ligereza y mezclándolas sin necesidad en las contiendas de los hombres». Lisa y llanamente esto significaba que, sin perder aquella fundamentación última, la política, en constante proceso de secularización, pensaba ya el RuIZ-GiméNEZ de 1957-1958, no es ni debe ser Opus Dei, ni Ratio Dei, sino Opus Hominis, Ratio Hominis. Y además, reivindicando con otros términos y con otras connotaciones que las actuales esa necesaria autonomía de la política, advertía a los tecnócratas que ya estaban entonces, y ahora, acaparándolo todo, «que —estas son sus palabras - no es el experto o técnico en economía, en administración, en logística, en arte bélico o en cualquiera de las otras disciplinas que contribuyen al bienestar colectivo, el que debe dirigir la vida de la comunidad».

18 J. RuIZ-GimÉnEZ, La política, deber y derecho del hombre, Madrid, Epesa, 1958, p. 22. Es, como allí se indica, el texto «con leves variantes de redacción», y con unas nuevas «Palabras a modo de Prólogo» (pp. 7-19) de la conferencia pronunciada en solemne acto en el Colegio Mayor «Santa María» de la Universidad de Madrid, el día 28 de mayo de 1957, reproducida en ese mismo año por la Revista de Estudios Políticos, núm. 94. Tanto la conferencia como el posterior breve libro, por él se cita aquí, encontraron amplia difusión y discusión en los ambientes políticos y universitarios de aquellos días. 
Y en aquel contexto político español, en que él mismo recelaba todavía de los partidos políticos, por su carácter fragmentador del «principio mínimo de unidad y de concordia» (¡cuantas discusiones mías con él acerca de estas y otras cuestiones!), avisa sin embargo de que había, por otro lado, que «precaverse contra los sucedáneos de los partidos, no ya clandestinos, sino manifiestos; para ser más claro — protestaba RUIZ-GIMÉNEZ - contra los grupos o camarillas que traten de ejercer la misma acción política de los partidos, pero sin su gallardía y responsabilidad». Frente a todas esas políticas, RUIZ-GIMÉNEZ propugnaba repetidamente, aunque - como digo- no sin residuos de autentificación de la democracia orgánica, que «todo hombre tiene derecho a participar directa y personalmente en la vida de la comunidad política de que es miembro». Y establecía «entre las exigencias fundamentales de cualquier régimen político justo» que nadie podía ser discriminado ni excluido de la comunidad política y que, por tanto - la referencia era explícita y casi explosiva en aquella España y hasta el final mismo del franquismo-, que tampoco podían ser excluidos ni discriminados quienes habían perdido la guerra civil. RUIZ-GimÉnEZ recurre allí al amparo de la carta VII de Platón a sus amigos de Siracusa aconsejándoles — dice textualmente«grandeza de alma y voluntad de integración de los vencidos como condición de la estabilidad futura del Estado» ${ }^{19}$.

El proceso, la evolución, se iba a acelerar y acentuar — como sabemos- desde esos muy iniciales años sesenta y a lo largo de los posteriores tiempos ya hasta el final. RuIZ-GIMÉNEZ, son los años de Cuadernos para el Diálogo, los va a vivir con especial intensidad. Se consolidan y avanzan en él los principios de racionalidad, de modernidad, de correlativa aceptación de la filosofía política democrática, de defensa de la legalidad y legitimidad constitucional, de un Estado no centralista sino capaz de coordinar la pluralidad nacional, de una crítica a la soberanía ilimitada de los Estados en pro de una Justicia penal internacional, de la extensión y protección efectiva de los derechos humanos (de manera muy especial los derechos sociales, económicos y culturales) en el marco de un auténtico Estado de Derecho. Esas van a ser ya con carácter definitivo las nuevas conclusiones derivadas, ahora con plena coherencia, por J. RUIZ-GimÉnEZ desde aquellos grandes principios y fundamentos que con recta intención siempre ha-

19 Para estos pasajes de la publicación citada en la nota anterior, $c f r$. pp. 14-15, 22, 50, 54, 69 a 72 entre otras. Las escasas cursivas o términos entrecomillados aquí conservados corresponden — quiero resaltarlo- al propio RuIZ-GiméNEZ. Sobre las dependencias todavía respecto del anterior régimen, cfr. las pp. 14-15, 16, 18, 60 a 62, entre otras. En la obra La política en el régimen de Franco entre 1957 y 1969. Proyectos, conflictos y luchas por el poder (Madrid, Centro de Estudios Políticos y Constitucionales, 2006), su autor P. HISPÁN IGLESIAS DE USSEL me menciona a propósito de este comentario mío y, en concreto, en relación con esa última observación, me ve (p. 45, nota 61) «haciendo — dice- una interpretación muy personal, ya que en ningún momento se refirió [RUIZ-GIMÉNEZ], como cree recordar DíAZ, a los vencidos en la guerra civil»: ahora estas cursivas son mías. Pero yo no decía allí (ahí está el texto) ni digo aquí, que RuIZ-GiménEz dijera explícitamente «en la guerra civil» (supongo que «española», le aduciría yo a su vez a mi objetor). Soy yo quien lo dice: hay, como vemos, sobreentendidos que no precisan, o no permiten, mayor explicación. Así lo entendimos entonces todos los presentes, y no pocos de los ausentes que lo comentaban y criticaban después. Pero, con la mayor sinceridad posible ¿a que vencidos cree P. Hispán IGLESIAS DE USSEL que —con Platón como pretextoquería aludir RUIZ-GIMÉNEZ con ese énfasis y en tal solemne ocasión? ¿A los troyanos y troyanas (EURÍPIDES) o a los vencidos de la guerra civil española, por lo demás también con su «quinta columna» dentro de Madrid, como el famoso caballo de Troya? De todos modos, a lo largo de los años sesenta las cosas ya quedaron claras: seguidores tecnócratas del «Opus Dei» versus colaboradores demócratas de Cuadernos para el Diálogo. Y así hasta hoy mismo. 
bía defendido: la dignidad humana, el respeto a la conciencia personal, el Estado al servicio del hombre, la paz, la justicia, la solidaridad ${ }^{20}$.

De lo que se trataba en su proyecto en este tiempo nuevo era de contribuir a que todo eso se hiciese realidad, de introducirlo en las consecuentes acciones prácticas y políticas; pero también, para que tales propuestas alcanzaran suficiente respaldo, apoyo social, legitimación, era necesario a su vez, argumentar, dar razones, unamuniamente no ya vencer, sino convencer, dialogar. Y todo eso requería entonces un trabajo de construcción teórica, científica (de ciencias sociales, jurídicas, políticas, económicas) y desde luego que también de cualificación filosófica, de razón práctica y ética: otra vez, ciencia y conciencia. Me parece que esa doble tarea es la que estaba en la mente de quienes, promovidos y dirigidos por J. Ruiz-GiméneZ, con P. AltARES como principal colaborador y ejecutor, tuvimos la fortuna, y la virtud, de poder estar con él en la inolvidable puesta en marcha de Cuadernos para el Diálogo, ideada tiempo atrás y materializada en aquel lejano otoño de 1963 (su primer número apareció en el mes de octubre). Allí, en esos trece años de puntual presencia mensual hasta 1976 y en los centenares de libros y folletos editados (ya lo he recordado), está buena parte de la cultura plural en la oposición a la dictadura sin la cual no se entiende la cultura de la transición y, después, Constitución incluida, la construcción de la democracia en nuestro país ${ }^{21}$.

En el aspecto que aquí más directamente nos incumbe, el relacionado con la persona del profesor J. RuiZ-GiméNEZ en su faceta más universitaria e intelectual, tengo que señalar que los escritos por él allí publicados —y que, como ya se indicó, se han recopilado en dos gruesos volúmenes bajo el título de El camino hacia la democraciason precisamente la expresión concreta de esa cultura, de esa ética y esa política en ese

20 Junto a otros trabajos que expresan su evolución en esos años, recordaría aquí el artículo «Derecho y diálogo», Revista de Estudios Políticos, núm. 109, Madrid, enero-febrero de 1960; también, aún con el pie forzado de manual escolar, su obra sobre La propiedad. Sus problemas y su función social, 2 vols., Madrid y Salamanca, Ediciones Anaya, 1961 y 1962: y, sobre todo, su edición de la Encíclica «Pacem in Terris», de Juan XXIII, de 11 de abril de 1963, con Presentación y sinopsis y notas del profesor J. RuIZ-GIMÉNEZ, Madrid, Ediciones y Publicaciones Españolas, S. A., 1963.

21 J. GARCÍA-VELASCO en su colaboración, «Cuadernos» en la tradición universitaria institucionista, al volumen colectivo citado aquí en la nota tercera, ha llamado certeramente la atención sobre las analogías, sin desconocer las diferencias, de la acción educadora, política y cultural llevada a cabo en el entorno plural de Cuadernos para el Diálogo, con algunas de las repercusiones públicas y las empresas intelectuales derivadas, de un modo u otro, en el primer tercio de siglo, a partir de la «Institución Libre de Enseñanza». Escribe así (pp. 176-177): «Cuadernos era mucho más que una revista. Era, desde luego, una empresa intelectual, como lo habían sido antes de la guerra civil, las empresas periodísticas de Ortega, Azaña o Urgoiti: España, El Sol, Revista de Occidente. Pero también era un foco de irradiación intelectual que, en muchos sentidos, sustituyó el papel que debía cumplir la Universidad de aquellos años, como entre 1910 y 1936 lo habían sido las instituciones de la Junta para Ampliación de Estudios, singularmente el Centro de Estudios Históricos, dirigido por Ramón Menéndez Pidal y la Residencia de Estudiantes, por Jiménez Fraud». De hecho — volvería a recordar yo—en la Editorial de Cuadernos para el diálogo se publicaron las primeras tesis doctorales, que se habían llevado a cabo a sugerencia mía con plena aceptación y formal dirección de RUIZ-GIMÉNEZ, sobre institucionistas, discípulos de F. Giner de los Ríos, como A. PosAda (por F. LAPORTA) y los, además, socialistas como J. BesteIRo (por E. LAMO DE EsPinOSA) o F. DE LOS Ríos (por V. ZAPATERO), sobre el discípulo de J. SANZ DEL Río e introductor de la Sociología en España, M. SALES y FERRÉ (por M. NúÑEZ ENCABO), así como la de E. FERNÁNDEZ sobre marxismo y positivismo en el socialismo español, todas ellas precedidas de mi propio libro sobre La filosofía social del krausismo español, de 1973. Recuérdese, por lo demás, que a algunos de aquellos intelectuales, institucionistas u orteguianos, liberales o socialistas, los había tenido y apreciado el joven católico RUIZ-GIMÉNEZ como profesores en su época de estudiante en los cursos de la Facultad de Derecho y, después, de la Facultad de Filosofía en la Universidad de Madrid durante los años treinta, antes de la guerra civil: pienso que algo de aquellos impregnó y permaneció en su posterior talante personal e intelectual. 
tiempo de España. Pero también son, a mi juicio, piezas muy valiosas para la reconstrucción de una Teoría del Derecho y una Teoría de la Justicia de esa sólo aparentemente preterida Filosofía jurídica del, durante ese tiempo, catedrático de la asignatura en la Universidad (Central, luego Complutense) de Madrid. A dicha obra - trece años de trabajo, ciento sesenta y cinco escritos- hay, pues, que recurrir (y, tal vez, también a muchos de los editoriales que, siempre con su firma como presidente, han aparecido durante todos esos últimos tiempos en las «Noticias del Unicef» en España) para documentar, constatar y debatir con mayor detenimiento y amplitud sobre los fragmentos, pero siempre con conciencia de totalidad, de esa filosofía jurídica y política del profesor RuIZ-GimÉNEZ que aquí sólo en sus más amplios trazos y en memoria suya he pretendido yo esbozar ${ }^{22}$.

22 J. RuIZ-GIMÉnEZ, El camino hacia la democracia. Escritos en «Cuadernos para el Diálogo» (1963-1976), 2 vols., Madrid, Centro de Estudios Constitucionales, 1985 (Edición y Estudios «Instituto Fe y Secularidad», con Presentación de su Director Académico J. Gómez CAFFARENA). La obra —a la que ya me he referido en otras ocasiones - incluye también interesantes estudios sobre las diversas dimensiones de su pensamiento, así como una entrevista a aquél realizada por J. A. GIMBERNAT y una cronología esquemática preparada por T. RODRíGUEZ DE LECEA. Pienso que la circunstancia, teórica y política, personal y general, a que se ha venido aludiendo aquí, puede también encontrar ilustración y complemento en dos libros de, precisamente, los dos antiguos adjuntos de RUIZ-GiméNEZ: el mío, Los viejos maestros. La reconstrucción de la razón (Madrid, Alianza Editorial, 1994) y, sobre todo, el de G. PeCES-BARBA, La democracia en España: Experiencias y reflexiones (Madrid, Temas de Hoy, 1996). 